\title{
Spesialnummer for Virak-konferansen 2017
}

\author{
Eystein Gullbekk ${ }^{1}$, Karen Johanne Buset ${ }^{2}$, Astrid Heltne ${ }^{3}$, Hilde Terese Drivenes \\ Johannessen $^{4}$, Gry Bettina Moxnes ${ }^{5}$, Bente Svendsen ${ }^{3}$ \\ Universitetet i Oslo ${ }^{1}, \mathrm{NTNU}^{2}$, Handelsh $\phi y$ skolen $\mathrm{BI}^{3}$, Universitetet i Agder ${ }^{4}$, OsloMet - \\ storbyuniversitetet ${ }^{5}$
}

Kontakt:post@noril.uib.no

\section{Leder}

Filosofen og bibliotekaren G.W Leibniz så for seg en «bibliografisk organisasjon som kunne gi de lærde lett tilgang til alt som var skrevet om deres emner» (Gjersdal, Redse \& Moseid, 2018). Universitets- og høgskolebibliotekene har realisert denne visjonen under skiftende historiske omstendigheter, skiftende utdannings- og kunnskapspolitiske regimer, og ikke minst innenfor ulike teknologiske virkeligheter.

I vår tid forstår vi selvsagt bibliotekene som åpnere institusjoner enn det vi leser ut av Leibniz' vekt på å utvikle en «bibliografisk organisasjon for de lærde». Bibliotekene er nå også viktige når utdanningsinstitusjonene skal skape arenaer der studentene deltar $\mathrm{i}$ aktive læringsformer, de er viktige når kunnskap skal formidles bredt og tas i bruk i arbeidsliv og $\mathrm{i}$ offentlig ordskifte, og de er viktige for åpenhet i den faglige vitenskapelige kommunikasjonen. Ikke minst er de viktige når utdanningsinstitusjonene skal skape nye sammenhenger mellom digitale tjenester og fysiske arealer og samhandlingsformer.

Tilgang handler i dag om at både forskere og studenter - og allmenheten for øvrig - skal ha friest mulig adgang til faglige kilder og annen informasjon. Tilgjengelighet handler om løsninger og tjenester som setter forskere, studenter - og andre - i stand til å realisere tilgangen. Tilgjengelighet er ikke noe som oppstår av seg selv ved at tilgang er gitt. Det er en utfordring bibliotekene må løse gjennom eget utviklingsarbeid, og ikke minst i partnerskap med hverandre og universitets- og høyskolemiljøene de er en del av.

«Virak-konferansen for universitets- og høyskolebibliotek» satte tilgang og tilgjengelighet som tema for sin første konferanse. Konferansen ble arrangert i samarbeid mellom bibliotekene ved Høgskolen i Oslo og Akershus (nå OsloMet - storbyuniversitetet), Handelshøyskolen BI og Universitetet i Oslo den 12.-13 juni 2017. Konferansen er en videreføring av UHbibliotekkonferansen og eies av UHR Bibliotek.

Nordic Journal of Information Literacy in Higher Education, 2018. @2018 Eystein Gullbekk, Karen Johanne Buset, Astrid Heltne, Hilde Terese Drivenes Johannessen, Gry Bettina Moxnes, Bente Svendsen.

This is an Open Access article distributed under the terms of the Creative Commons Attribution Noncommercial 4.0 Unported License (http://creativecommons.org/licenses/by-nc/4.0/) 
Virak-konferansen belyser bibliotekenes samhandling med sine moderinstitusjoner. Den har også valgt formater for presentasjon og diskusjon som i høyest mulig grad kan fremme samarbeid, diskusjon og engasjement, slik som PechaKucha-sesjoner, prosjektdating og digital historiefortelling, i tillegg til mer tradisjonelle paperframlegg. Bidragene som ble antatt til konferansen reflekterte konferansens tematiske bredde. Invitasjonen vi sendte ut rommet følgende spørsmål:

- Hvordan setter vi brukerne i stand til å nyttiggjøre seg kilder, teknologier og bibliotekrom?

- Hvilket potensial ligger i elektroniske formater?

- Hvilken rolle spiller nye typer materiale og publikasjonsformer?

- Hvordan arbeider vi med åpen vitenskap?

- Hvordan veileder vi studenter og forskere?

- Hva slags type informasjonskompetanse bør understøttes og utvikles?

- Hvordan ivaretas personvernet?

- Hvilke sammenheng er det mellom tilgjengeliggjøring og informasjonsdeling?

- Hvilke arenaer skal bibliotekene være?

- Hvordan måler vi kvaliteten på våre tjenester?

- Hvilken teknologi bør utvikles og/eller implementeres?

- Hvilken kompetanse trenger bibliotekets ansatte når forskning, undervisning, teknologi og formater endrer seg?

Deltagere som stilte med bidrag i konferansen ble invitert til skrive artikler for et spesialnummer i NORIL. Resultatet er de seks artiklene i dette spesialnummeret. Artiklene problematiserer og illustrerer bibliotekenes arbeid med tilgjengeliggjøring innenfor et vidt spenn av temaer og områder.

«Learning analytics» handler om å samle og analysere ulike former for informasjon om studenters resultater og handlinger, der målet er å forbedre læringsprosessene. Hoel, Chen og Gregersen har i sin artikkel undersøkt hvordan norske bibliotekarer forholder seg til fenomenet «library analytics». I hvilken grad er de villig til å gi slipp på det dypt forankrede prinsippet om å la all informasjon om bibliotekbruk forbli mellom bruker og bibliotekar? Er tiden inne for å gi fra seg bibliotekdata og samarbeide med andre for å optimalisere studentenes læring?

Nye discovery-system gir mulighet til å søke i et bredere spekter av ressurser enn man har mulighet til i tradisjonelle bibliotekkataloger, men de kan også være mer utfordrende for brukerne. I sin artikkel analyserer Huurdeman, Aamodt og Hegg $\varnothing$ transaksjonslogger fra Oriasøk ved UiO. De identifiserer hvilke typer søkespørsmål som ofte stilles. I artikkelen redegjør de bl.a. for typer søkespørsmål som ikke gir resultat, selv om litteraturen det søkes etter finnes i biblioteket. Forfatterne har unders $\varnothing \mathrm{kt}$ underliggende årsaker til at søk ikke gir resultat og peker på forbedringsmuligheter i søkesystemet.

I hvilken grad er et discovery-system som Primo et alternativ til spesialdatabaser? Dabin og Preminger har i artikkelen sin sammenlignet søkeresultat fra Primo og fire av BIs spesialdatabaser. Artikkelen gir en grundig gjennomgang av søkeprosess og overlapp i søkeresultat, og diskuterer i hvilke sammenhenger ulike verktøy kan foretrekkes.

Med utgangspunkt i studier blant norske elever ved videregående skole og studenter i høyere utdanning, spør Greek og Jonsmoen hvordan skriveveiledningen i høyere utdanning bør 
utformes. De sammenligner ferdighetene elevene har med seg fra videregående med det som kreves av dem når de kommer på et universitet. Forfatterne understreker fagskriving som del av disiplinære diskurser. I artikkelen diskuterer de hvordan ulike aktører - forelesere, bibliotekarer og skrivepedagoger - kan supplere hverandre og bidra til å gjøre studentene til bedre fagskrivere.

Nye krav til forskere og studenter om å gjøre forskningsdata tilgjengelige gir radikalt nye utfordringer for bibliotekene. Conzett og Østvand tar i sin artikkel for seg arbeidet knyttet til åpne forskningsdata ved UiT - Norges arktiske universitet. De redegjør for hvordan UiT systematisk har arbeidet frem retningslinjer, tekniske løsninger, rutiner og kurs for åpne forskningsdata. Artikkelen gir en grundig gjennomgang av ulike aspekter som bør vurderes og planlegges før man setter i gang med åpne forskningsdata.

$\AA$ lage systematiske litteraturoversikter er en svært ressurskrevende oppgave. Gundersen, Korvald, Grønlund, Karlsen, Tangen, Thorvik og Ødemark skriver om etableringen av en ressursgruppe for litteraturs $\varnothing \mathrm{k}$ på OsloMet - storbyuniversitetet. I artikkelen tar de for seg bakgrunnen for etableringen av en slik tjeneste, de gir en grundig beskrivelse av tjenesten samt de erfaringene ressursgruppen har gjort.

Vi ønsker god lesning, og oppfordrer våre lesere til å følge med på neste Virakkonferanse som vil arrangeres i 2019.

Virak-komiteen

\section{Referanser}

Gjersdal, A. Redse,T. \& Moseid, TE. (2018). Bibliotek. I Store norske leksikon. Retrieved from https://snl.no/bibliotek 